\title{
Quality of Life and Graduation in Medicine
}

\section{Qualidade de Vida e Graduação em Medicina}

\author{
Isabela Maria Melo Miranda ${ }^{I}$ (iD \\ Helen Hana Fernandes Tavares ${ }^{I}$ (iD \\ Heloísa Rodrigues Soares da Silva ${ }^{I}$ (D) \\ Monise Santana Braga ${ }^{I}$ (BD \\ Raquel de Oliveira Santos ${ }^{I}$ (D) \\ Heloísa Silva Guerra ${ }^{I}$ iD
}

\section{KEYWORDS}

- Quality of Life.

- Medical Students.

- Mental Health.

Introduction: In recent years, the quality of life of medical students has been questioned, given the context in which they are inserted. Stress as a result of the number of long hours, difficulty in reconciling academic and personal life, exposure to situations of pain and suffering, have been shown to be the main factors for the decrease in quality of life of these students. The aim of this study was to assess the quality of life of medical students and its associated factors. Method: Cross-sectional study with 419 medical students from a public institution in Goiás. The study was carried out with students over 18 years old and enrolled in the second to the eighth semester of medical school, between 2017 and 2018. Sociodemographic and lifestyle questionnaires and the World Health Organization Questionnaire for Quality of Life - Brief Form (WHOQOL-BREF) were used. Results: The factors related to low quality of life were: female gender, the use of stimulants, thinking about giving up medical school and having comorbidities. Those related to a better quality of life were consuming fruits and vegetables, practicing physical activity, more sleeping time and stress management. Conclusion: This study found a set of factors capable of interfering with the quality of life of these students, suggesting the need for interventions aimed at pedagogical and psychological support. 


\section{RESUMO}

\section{PALAVRAS-CHAVE}

- Qualidade de Vida.

- Estudantes de Medicina.

- Saúde Mental.

Introdução: Nos últimos anos, tem-se questionado sobre a qualidade de vida dos estudantes de Medicina dado o contexto em que estão inseridos. O estresse como resultado do somatório de carga horária extensa, dificuldade de conciliar a vida acadêmica com a pessoal e exposição a situações de dor e sofrimento tem-se mostrado como o principal fator para a queda da qualidade de vida desses acadêmicos. O objetivo deste estudo foi avaliar a qualidade de vida de acadêmicos de Medicina e seus fatores associados. Método: Trata-se de um estudo transversal realizado com 419 acadêmicos do curso de Medicina de uma fundação pública de Goiás. Foram incluídos alunos a partir de 18 anos e matriculados no curso do segundo ao oitavo período, de 2017 a 2018. Utilizaram-se os questionários sociodemográfico e de hábitos de vida e o World Health Organization Questionnaire for Quality of Life - Brief Form (WHOQOL-bref). Resultados: Os fatores relacionados com a baixa qualidade de vida foram: sexo feminino, utilizar estimulantes, pensar em desistir do curso e possuir comorbidade. Os relacionados com melhor qualidade de vida foram consumir frutas e hortaliças, praticar atividade física, mais tempo de sono e gestão do estresse. Conclusão: Este estudo encontrou um conjunto de fatores capazes de interferir na qualidade de vida desses estudantes, sugerindo a necessidade de intervenções direcionadas ao apoio pedagógico e psicológico.

Received on $04 / 24 / 20$

Accepted on 05/02/20

\section{INTRODUCTION}

Quality of life (QOL) according to the World Health Organization (WHO) is a broad concept understood as physical health, psychological status, level of independence, social relations, beliefs and relationships. It is defined as the individuals' perception in relation to their position in life, in the cultural context and their goals, expectations, standards and concerns ${ }^{1}$.

In recent years, the quality of life of medical students has been questioned, given the context in which they are inserted. Stress as the result of long hours of work, difficulty in reconciling academic and personal life, exposure to situations of pain and suffering, reduced leisure time and a competitive environment has been shown to be the main factors for the decrease in quality of life of these students ${ }^{2}$.

Medical students (MS) learn to promote health care in their patients; however, they often neglect their own care, which is reflected in their quality of life. In this paradoxical scenario, they sometimes associate health care with the vulnerability of a patient, denying themselves the need for selfcare to maintain their physical and mental well-being. The medical learning environment itself can often bring feelings of self-sufficiency, leading future doctors to consider themselves strong enough to withstand exhausting routines and situations of extreme emotional demand, without seeking help ${ }^{3}$.

These stressors of the medical school can affect the quality of life and influence the students' physical and mental health. Aiming to understand the possible interpositions in the academic education process, this study aimed to assess the quality of life of medical students and contribute with information that can subsidize interventions that will help both in the quality of life of these students and in their professional qualification process.

\section{METHODS}

This was a cross-sectional study, carried out with students from the second to the eighth semesters of the undergraduate medical course in the year 2017 to 2018 from a public institution in the countryside of the state of Goiás. The inclusion criteria comprised being 18 years or older and being duly enrolled in the medical course.

Two instruments were used for data collection: one on sociodemographic and lifestyle data, and the World Health Organization Questionnaire for Quality of Life - Bref Form (WHOQOL-bref).

The WHOQOL-bref is an instrument developed by the World Health Organization (WHO) and validated in Brazil ${ }^{1,4}$. It is an abbreviated version of the World Health Organization Questionnaire for Quality of Life - 100 (WHOQOL-100), consisting of 24 questions representing each of the 24 parts that comprise the original instrument, divided into four domains that aim to verify the physical capacity (seven questions), the psychological well-being (six questions), the social relations (three questions) and the environment where the individual is inserted (eight questions), as well as two general questions of QOL. The Portuguese version of the WHOQOL-bref was considered to have good internal consistency, satisfactory in terms of discriminant, concurrent and content validity; and adequate test-retest reliability ${ }^{4}$.

The data were analyzed using the STATA program, version 14.0 (StataCorp, 2015). The Kolmogorov-Smirnov test with Lilliefors correction was performed to verify the normality of the quantitative variables of the study. The qualitative variables were descriptively presented as absolute (n) and relative (\%) frequencies and the quantitative variables as mean and standard deviation (SD), minimum and maximum values. For the dimensions of the quality of life instrument, the median, $95 \% \mathrm{CI}$ of the mean and interquartile range (IQR) were also presented.

Cronbach's alpha coefficient for internal consistency and the intraclass correlation coefficient (ICC) were used for the analysis of WHOQOL-bref reliability and internal consistency.

To verify the factors associated with the QOL domains, bivariate and multiple analyses were performed. In the bivariate analysis, Student's $t$ tests for independent samples or analysis of variance (ANOVA) were used to compare the mean scores of the QOL domains between the nominal and ordinal variables, respectively. Then, multiple linear regression analysis was performed with the QOL domains as the dependent variables. Variables with a p-value $<0.20$ and gender and age were included in the regression models as potential confounding variables. Values of $\mathrm{p}<0.05$ were considered statistically significant for all analyses. 
The study was approved by the Research Ethics Committee of Fundação do Ensino Superior de Rio Verde - FESURV - Universidade de Rio Verde through Opinion N. 2288371, CAAE 69111317000005077, on September 21, 2017.

\section{RESULTS}

The reference population consisted of 419 students enrolled from the second to the eighth semesters of the medical course. Most of the research participants were females (64.7\%), with a mean age of 22.1 (SD \pm 4.3 ) years and were single (96.2\%) (Table 1). Approximately $25.1 \%$ reported using stimulant substances sometimes and $9.3 \%$ always used them. A total of $28.6 \%$ thought about giving up the course and $32.5 \%$ reported that they only sometimes felt able to manage stress.

Regarding lifestyle habits, $61.3 \%$ did not eat fruits and vegetables according to recommendations; $40.3 \%$ consumed hypercaloric foods; $59.7 \%$ practiced physical exercises on a regular basis; $95.7 \%$ never smoked; $62.5 \%$ used alcohol and $17.4 \%$ reported having comorbidities.

Table 2 shows the descriptive analysis of the QOL domains of MS, as well as the internal consistency tests. It was observed that the highest QOL score was found in the environmental domain (68.8) and the lowest in the

\begin{tabular}{|c|c|c|}
\hline \multicolumn{3}{|c|}{$\begin{array}{l}\text { Table } 1 \\
\text { Distribution of the characteristics of medical students at an } \\
\text { institution in the Brazilian Midwest. Aparecida de Goiânia, GO, } \\
\text { Brazil, } 2018 .\end{array}$} \\
\hline Variables & $\mathbf{n}$ & $\%$ \\
\hline \multicolumn{3}{|l|}{ Gender } \\
\hline Male & 148 & 35.3 \\
\hline Female & 271 & 64.7 \\
\hline \multicolumn{3}{|l|}{ Marital status } \\
\hline Not married & 403 & 96.2 \\
\hline Married & 16 & 3.8 \\
\hline \multicolumn{3}{|c|}{ Extracurricular activities } \\
\hline No & 172 & 41.1 \\
\hline Yes & 247 & 58.9 \\
\hline \multicolumn{3}{|l|}{ Use of stimulants } \\
\hline Never & 275 & 65.6 \\
\hline Sometimes & 105 & 25.1 \\
\hline Always & 39 & 9.3 \\
\hline \multicolumn{3}{|c|}{ Thinks about giving up the course } \\
\hline No & 299 & 71.4 \\
\hline Yes & 120 & 28.6 \\
\hline \multicolumn{3}{|l|}{ Sleeps well } \\
\hline Always & 11 & 2.6 \\
\hline Almost always & 211 & 50.4 \\
\hline Sometimes & 142 & 33.9 \\
\hline Almost never & 44 & 10.5 \\
\hline Never & 11 & 2.6 \\
\hline
\end{tabular}

Continue... psychological domain (62.3).

In the bivariate analysis of the factors associated with the QOL domains, it was observed that the QOL scores were lower in women than in men in the physical (p-value $<0.001$ ), psychological (p-value $<0.001$ ) and environmental $(\mathrm{p}$-value $=0.001)$ domains.

Students who reported thinking about giving up medical school had lower QOL scores than those who did not report this characteristic in all domains (p-value $<0.001$ ).

Also, those who reported always or sometimes using stimulants, had lower QOL scores in the physical ( $\mathrm{p}$-value $<0.001$ ), psychological ( $\mathrm{p}$ $<0.001$ ), social ( $\mathrm{p}$-value $<0.005$ ) and general ( $\mathrm{p}$ - value $<0.002$ ) domains. MS who reported having comorbidities had lower QOL scores in the physical domain ( $\mathrm{p}$-value $<0.021$ ) and those who reported consuming the recommended amounts of fruits or vegetables had higher QOL scores in the physical ( $\mathrm{p}$-value $=0.032$ ) and general ( $\mathrm{p}$ - value $<0.001)$ domains.

Students who reported regular physical activity had higher QOL scores in almost all domains ( $\mathrm{p}$-value $<0.05$ ), except in the social domain. Smokers had lower QOL scores in the general domain ( $\mathrm{p}$-value $=0.045$ ).

Regarding the quantitative variables, the higher the number of hours of sleep, the higher the QOL in all domains (p-value $<0.05$ ). Furthermore,

\begin{tabular}{|c|c|c|}
\hline \multicolumn{3}{|c|}{ Continuation } \\
\hline Variables & $\mathbf{n}$ & $\%$ \\
\hline \multicolumn{3}{|c|}{ Feels able to manage stress } \\
\hline Always & 30 & 7.2 \\
\hline Almost always & 223 & 53.2 \\
\hline Sometimes & 136 & 32.5 \\
\hline Almost never & 25 & 6.0 \\
\hline Never & 5 & 1.2 \\
\hline
\end{tabular}

Recommended consumption of fruits/ vegetables

$\begin{array}{lll}\text { No } & 257 & \mathbf{6 1 . 3} \\ \text { Yes } & 162 & 38.7\end{array}$

Consumption of high-calorie foods

$\begin{array}{lll}\text { No } & 250 & 59.7\end{array}$

$\begin{array}{lll}\text { Yes } & 169 & 40.3\end{array}$

Regular exercises

$\begin{array}{lll}\text { No } & 169 & 40.3 \\ \text { Yes } & 250 & \end{array}$

\begin{tabular}{ccc}
\hline Yes & 250 & 59.7 \\
Smoking & & \\
Never & 401 & 95.7 \\
Former smoker & 9 & 2.1 \\
Smoker & 9 & 2.1 \\
\hline Comorbidities & & \\
No & 346 & 82.6 \\
Yes & 73 & 17.4 \\
\hline Alcohol consumption & & \\
No & 157 & 37.5 \\
Yes & 262 & 62.5 \\
Total & 419 & 100
\end{tabular}

Source: research data. 


\begin{tabular}{|c|c|c|c|c|c|c|c|c|}
\hline Domains & Mean (SD) & $95 \% \mathrm{CI}$ & Median & IQR & $\begin{array}{c}\text { Value } \\
\text { Min. - Max. }\end{array}$ & $\begin{array}{c}\text { Cronbach's } \\
\text { alpha }\end{array}$ & ICC & p-value ${ }^{*}$ \\
\hline Physical & $63.2(14.7)$ & $61.8-64.6$ & 64.3 & $45.6-75.0$ & $21.4-100.0$ & 0.764 & 0.758 & $<0.001$ \\
\hline Psychological & $62.3(15.0)$ & $60.9-63.7$ & 65.0 & $55.0-75.0$ & $20.0-95.0$ & 0.688 & 0.683 & $<0.001$ \\
\hline Social & $68.6(19.6)$ & $66.7-70.4$ & 75.0 & $58.3-75.0$ & $8.3-100.0$ & 0.711 & 0.701 & $<0.001$ \\
\hline Environmental & $68.8(13.3)$ & $67.6-70.1$ & 68.7 & $59.4-78.1$ & $31.2-100.0$ & 0.754 & 0.752 & $<0.001$ \\
\hline General & $67.9(19.3)$ & $66.1-69.8$ & 75.0 & $50.0-75.0$ & $0.0-100.0$ & 0.674 & 0.669 & $<0.001$ \\
\hline
\end{tabular}

Source: research data.

Abbreviations: SD: Standard deviation; 95\%CI: 95\% confidence interval; SD: Standard deviation; IQR: Interquartile range; Min: Minimum; Max: Maximum; ICC: intraclass correlation coefficient; ${ }^{*}$ F-test.

it was observed that the better the stress management, the better the QOL in all domains (p-value $<0.001$ ).

Table 3 shows the factors associated with the QOL domains obtained in the multiple regression analysis.

It was found that the female gender was negatively associated with the physical $(\beta=-3.239$; $p$-value $=0.010)$ and environmental $(\beta=-2.600$; $\mathrm{p}$-value $=0.048)$ domains. This suggests that women have a lower QOL level in these domains when compared to men.

The use of stimulants "sometimes" and "always" was negatively associated with the physical and psychological domains of QOL, suggesting that the use of these substances decreases the QOL of medical students.

Being a smoker was negatively associated with QOL in the general domain ( $\beta=-12.797$; $\mathrm{p}$-value $<0.028$ ). Thinking about giving up the medical course was negatively associated with the physical $(\beta=-6.713$; $p$-value $<0.001)$, psychological $(\beta=-10.051$; $p$-value $<0.001)$, social $(\beta=-10.159$; $p$-value $<0.001)$, environmental $(\beta=-5.013$; $p$-value $<0.001)$ and general $(\beta=-5.920$; $\mathrm{p}$-value $=0.002)$ domains, indicating that MS with this characteristic have a decrease in QOL in all domains, when compared to those who do not think about giving up the undergraduate course.

The recommended consumption of fruits or vegetables was positively associated with the general QOL $(\beta=3.731$; $\mathrm{p}$-value $=0.042)$. The regular practice of physical activity was positively associated with QOL in the physical $(\beta=3.899$; $\mathrm{p}$-value $=0.001)$, psychological $(\beta=3.024$; $\mathrm{p}$-value $=$ $0.016)$, environmental $(\beta=3.655$; $p$-value $=0.004)$ and general $(\beta=8.971$; p-value $<0.001$ ) domains, suggesting an increase in QOL with the practice of physical exercises.

The reporting of comorbidities was negatively associated with QOL in the physical domain $(\beta=-3.122$; $\mathrm{p}$-value $<0.001)$, suggesting that comorbidities decrease the QOL of MS.

It was observed that with each increase of one hour of sleep, QOL scores of MS increased for the physical $(\beta=1.278$; $p$-value $=0.029$ ), psychological $(\beta=1.636$; $p$-value $=0.007)$, environmental $(\beta=1.368$; p-value $=0.024)$ and general $(\beta=3.067$; $p$-value $<0.001)$ domains.

Finally, stress management was positively associated with all QOL domains. This suggests that the increase in the positive perception of MS that they can manage stress increased QOL in all domains.

\begin{tabular}{|c|c|c|c|}
\hline \multicolumn{4}{|c|}{$\begin{array}{l}\text { Factors associated with the QOL domains, obtained in the multiple } \\
\text { regression analysis, of medical students from an institution in the } \\
\text { Brazilian Midwest. Aparecida de Goiânia, Goiás, Brazil, } 2018 .\end{array}$} \\
\hline Domains & $\beta$ & $95 \% \mathrm{CI}$ & p-value \\
\hline \multicolumn{4}{|l|}{ Physical } \\
\hline Age (years) & -0.016 & $-0.275 ; 0.243$ & 0.903 \\
\hline \multicolumn{4}{|l|}{ Gender } \\
\hline Male (R) & & & \\
\hline Female & -3.239 & $-5.686 ;-0.793$ & 0.010 \\
\hline \multicolumn{4}{|c|}{ Use of stimulants } \\
\hline \multicolumn{4}{|l|}{ Never (R) } \\
\hline Sometimes & -3.221 & $-5.853 ;-0.589$ & 0.017 \\
\hline Always & -9.702 & $-13.704 ;-5.700$ & $<0.001$ \\
\hline
\end{tabular}

Thinks about giving up the course

No (R)

Yes

$-6.713 \quad-9.257 ;-4.169$

$<0.001$

Consumption of fruits/vegetables

No (R)

Yes

$-0.364 \quad-2.771 ; 2.042$

0.766

Consumption of high-calorie foods

No (R)

Yes

$-0.546$

$-2.839 ; 1.747$

0.640

Regular exercises

No (R)

Yes

3.899

$1.584 ; 6.213$

0.001

Comorbidities

No (R)

Yes

$-3.122$

$-6.183 ;-0.065$

$<0.001$

Continue...

4 \begin{tabular}{|l|l} 
REVISTA BRASILEIRA DE EDUCAÇÃO MÉDICA \\
\hline 4 (3) : e086; 2020
\end{tabular} 


\begin{tabular}{ccccc} 
& & Table 3 & & \\
Continuation & & \\
Smoking & Domains & $\beta$ & $\mathbf{9 5 \% C I}$ & p-value \\
\cline { 2 - 4 } & & & & \\
& Never (R) & & & \\
Former smoker & -2.137 & $-9.995 ; 5.719$ & 0.593 \\
$\quad$ Smoker & -3.322 & $-10.961 ; 4.315$ & 0.393 \\
\hline & 1.278 & $0.130 ; 2.425$ & $\mathbf{0 . 0 2 9}$ \\
\hline Hours of sleep & 3.852 & $2.275 ; 5.429$ & $<\mathbf{0 . 0 0 1}$
\end{tabular}

F value (p-value): $23.57(<0.001) R^{2}: 0.431$ adjusted $R^{2}: 0.412$ VIF: 1.14

\begin{tabular}{|c|c|c|c|}
\hline Psychological & $\beta$ & $95 \% \mathrm{CI}$ & p-value \\
\hline Age (years) & -0.111 & $-0.395 ; 0.172$ & 0.440 \\
\hline \multicolumn{4}{|l|}{ Gender } \\
\hline Male (R) & & & \\
\hline Female & -1.679 & $-4.228 ; 0.879$ & 0.196 \\
\hline \multicolumn{4}{|l|}{ Use of stimulants } \\
\hline Never (R) & & & \\
\hline Sometimes & -3.949 & $-6.757 ;-1.140$ & 0.006 \\
\hline Always & -7.955 & $-12.221 ;-2.689$ & $<0.001$ \\
\hline
\end{tabular}

Thinks about giving up the course

$$
\text { No (R) }
$$

Yes

$-10.051 \quad-12.792 ;-7.311<0.001$

Comorbidities

No (R)

Yes

$-0.708 \quad-3.923 ; 2.507$

0.665

Consumption of high-calorie foods

$$
\begin{gathered}
\text { No (R) } \\
\text { Yes }
\end{gathered}
$$$$
-1.506
$$

$-3.976 ; 0.964$

0.231

Regular exercises

$\begin{array}{cccc}\text { No }(\mathrm{R}) & & & \\ \text { Yes } & 3.024 & 0.559 ; 5.488 & \mathbf{0 . 0 1 6} \\ \text { Course semester } & 0.166 & -0.419 ; 0.750 & 0.577 \\ \text { Hours of sleep } & 1.636 & 0.448 ; 2.823 & \mathbf{0 . 0 0 7} \\ \text { Stress management } & 5.651 & 3.998 ; 7.305 & <\mathbf{0 . 0 0 1}\end{array}$

F value (p-value): $21.91(<0.001) R^{2}: 0.349$ adjusted $R^{2}: 0.333$ VIF: 1.08

\begin{tabular}{cccc} 
Social & $\beta$ & $95 \% \mathrm{CI}$ & p-value \\
\hline Age (years) & -0.207 & $-0.623 ; 0.208$ & 0.327
\end{tabular}

Gender

$$
\begin{gathered}
\text { Male (R) } \\
\text { Female }
\end{gathered}
$$$$
1.717
$$$$
-2.134 ; 5.569
$$

0.382

Use of stimulants

$\begin{array}{llll}\text { Never (R) } & & & \\ \text { Sometimes } & 0.354 & -3.827 ; 4.537 & 0.868 \\ \text { Always } & -4.709 & -11.049 ; 1.630 & 0.145\end{array}$

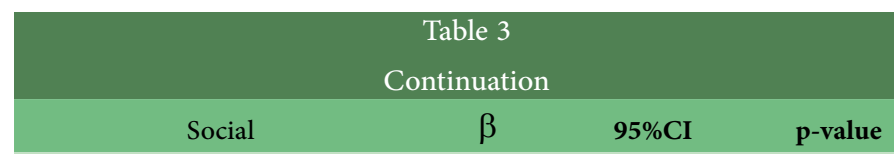

Thinks about giving up the course

No (R)

Yes

$-10.159-14.217 ;-6.102$

$<0.001$

Consumption of fruits / vegetables

No (R)

Yes

0.134

$-3.724 ; 3.993$

0.946

Consumption of high calorie foods

No (R)

Yes

$-3.177$

$6.870 ; 0.515$

0.091

Regular exercises

$\begin{array}{cccc}\text { No }(\mathrm{R}) & & & \\ \text { Yes } & 2.813 & -0.915 ; 6.541 & 0.139 \\ \text { Hours of sleep } & 0.917 & -0.843 ; 2.677 & 0.306 \\ \text { Stress management } & 5.367 & 2.922 ; 7.811 & <\mathbf{0 . 0 0 1}\end{array}$

F value (p-value): $7.48(<0.001) \mathrm{R}^{2}: 0.155$ adjusted $\mathrm{R}^{2}: 0.134$ VIF: 1.10

$\begin{array}{cccc}\text { Environmental } & \beta & 95 \% \mathrm{CI} & \text { p-value } \\ \text { Age (years) } & -0.341 & -0.620 ;-0.061 & \mathbf{0 . 0 1 7}\end{array}$

Gender

Male (R)

Female

$-2.600-5.178 ;-0.023$

0.048

Thinks about giving up the course

No (R)

Yes

$-5.013-7.708 ;-2.329<\mathbf{0 . 0 0 1}$

Consumption of fruits/vegetables

No (R)

Yes

$1.298 \quad-1.287 ; 3.883$

0.324

Consumption of high-calorie foods

No (R)

Yes

$\begin{array}{lll}-1.206 & -3.678 ; 1.266 & 0.338\end{array}$

Regular exercises

No (R)

Yes

$3.655 \quad 1.110 ; 6.160 \quad \mathbf{0 . 0 0 4}$

Hours of sleep

$1.368 \quad 0.183 ; 2.552 \quad 0.024$

Stress management

$3.278 \quad 1.658 ; 4.909$

$<0.001$

F value (p-value): $10.15(<0.001) \mathrm{R}^{2}: 0.165$ adjusted $\mathrm{R}^{2}$ : 0.149 VIF: 1.09

$\begin{array}{cccc}\text { General } & \beta & \mathbf{9 5 \% C I} & \text { p-value } \\ \text { Age (years) } & -0.449 & -0.845 ;-0.052 & \mathbf{0 . 0 2 7} \\ \text { Gender } & & & \\ \text { Male (R) } & & & \\ \text { Female } & -0.447 & -4117 ; 3.222 & 0.811 \\ & & & \text { Continue... }\end{array}$




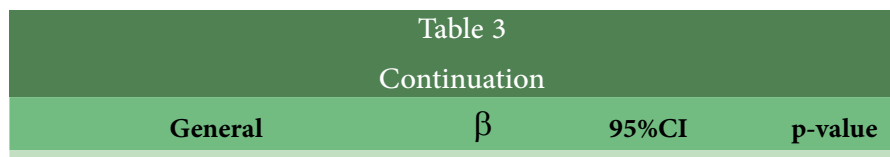

Thinks about giving up the course

No (R)

Yes $-5.920$

$-9.722 ;-2.119$

0.002

Use of stimulants

Never (R)

Sometimes

$-1.087$

$-5.029 ; 2.857$

0.588

Always

$-5.494$

$-11.493 ; 0.504$

0.072

Consumption of fruits/vegetables

No (R)

Yes

3.731

$0.132 ; 7.329$

0.042

Consumption of high-calorie foods

No (R)

Yes

$-0.351 \quad-3.788 ; 3.086$

0.841

Regular exercises

No (R)

Yes

8.971

$5.500 ; 12.442$

$<0.001$

Smoking

Never (R)

Former smoker

$1.661 \quad-10.117 ; 13.441$

0.782

Smoker

$-12.797$

$-24.208 ;-1.387$

0.028

Period

$-0.530$

$-1.339 ; 0.278$

0.198

Hours of sleep

3.067

$1.413 ; 4.720$

$<0.001$

Stress management

5.081

$2.792 ; 7.370$

$<0.001$

F value (p-value): $10.60(<0.001) \mathrm{R}^{2}: 0.254$ adjusted $\mathrm{R}^{2}$ : $0.230 \mathrm{VIF}: 1.11$

Source: research data

Abbreviations: 95\% CI: 95\% confidence interval; R: Reference category; $\beta$ : regression coefficient; VIF: Variance Inflation Factor - Test indicating the presence or absence of collinearity (the presence of a VIF> 0.4 indicates the presence of collinearity); R2 and adjusted R2: coefficient of determination (indicates the explanatory power of the model).

\section{DISCUSSION}

The profile of the students evaluated in this study was similar to those found in the literature, with the majority being females ${ }^{5,6}$, single, with a mean age of 22 years ${ }^{7,8,9,10}$. A different result was found in the study carried out at a public university in southern Brazil, where male students predominated $^{11}$.

Regarding quality of life, some factors were negatively related, namely: being female, sometimes and always using stimulants, thinking about giving up the course and having comorbidities. The factors related to better quality of life were the consumption of fruits and vegetables, physical activity, more hours of sleep, and stress management.

When analyzing the gender variable, this study found that being female was related to a worse quality of life in the physical and environmental domains. This result was similar to those of other authors. A study that evaluated the quality of life and factors associated with the lower quality of life score of medical students, showed that male students had higher scores in the physical, psychological domains, level of independence, quality of life and in the global score, when compared to women ${ }^{7,12}$. Other studies have reported worse quality of life scores among female students in the time use, physical and psychological domains ${ }^{13,14}$. This result can be justified by the physical and emotional changes that the female organism goes through, interfering in the sleep-wake cycle through variations in estrogen and progesterone ${ }^{15}$.

In the present study, the consumption of fruits and vegetables was associated with a better overall quality of life of the students. There is a deficit of articles in the literature that associate the medical students' quality of life to their diet. However, it is known that nutrition is a factor neglected by students, who eat more sugar, salt and fatty foods, due to practical and fast eating habits, such as the preference for industrialized products, low consumption of fruits, vegetables, and legumes and skipped meals ${ }^{16,17}$.

According to the results of this study and the literature, it is clear that the medical student has a poor diet, which, associated with the stress, increases the risk factors for the development of comorbidities. The latter have a proven negative association with quality of life, leading to the conclusion that these factors work as a vicious cycle of impaired quality of life. This condition represent an unfavorable contribution to the development of the skills and competences of medical practice and the relationship with the patient in the future professional activity ${ }^{18}$.

Considering the influence of physical activities on the quality of life, the present study observed that there was a positive association regarding the physical, psychological and environmental domains. The practice of sports activities has a relevant impact on the quality of life of students, and those who exercise three or more times a week for at least 30 minutes have higher quality of life scores in the physical, psychological and environmental domains ${ }^{8,12}$.

The presence of comorbidities had a negative impact on the medical students' quality of life, regarding the physical domain. This association corroborates other studies that also observed lower scores in the physical, psychological, social and environmental domains in students with comorbidities, especially psychiatric disorders, such as anxiety, panic and depression $^{8,10,19}$. Although the presence of psychiatric disorders among medical students is frequently observed, the number of students seeking treatment is very small. This result is possibly associated with the stigma these diseases carry, preventing them from seeking help and treatment. Therefore, students resist to admit the presence of these disorders, even when they have support ${ }^{20,21}$.

This study also observed that adequate stress management was positively related to all domains of students' quality of life. These data correlate with those in the study by Oliveira, who pointed out that there is a 6.2-fold worsening in the quality of life when stress is perceived ${ }^{22}$.

Regarding the hours of sleep, it was observed that with each additional hour of sleep, the student demonstrates an increase in the quality of life for the physical, psychological, environmental and general domains. Medical students have a worse quality of life when compared to the general population in the fields of psychological health and social relations; and this is greatly affected by burnout and difficulty sleeping. Moreover, sleep difficulties affect their daily work and increase the sensitivity to stressful medical learning experiences ${ }^{3,23}$.

A study carried out with medical students in the extreme south of Brazil, showed a high prevalence $(52.3 \%)$ of the use of psychostimulants

$6 \mid$\begin{tabular}{|l|l} 
REVISTA BRASILEIRA DE EDUCAÇÃO MÉDICA \\
44 (3) : e086; 2020
\end{tabular} 
among students. The most important reasons for such use were compensation for sleep deprivation (47.4\%) and improved reasoning, attention and/or memory (31.6\%). Regarding the effects, it showed an association between the use of psychostimulants and the increase in stress levels. These findings reinforce the data observed in the present study, which indicate that both the use of stimulants and the motivation to use them (sleep deprivation) are related to negative effects on the student's quality of life $\mathrm{e}^{24}$.

When analyzing the thought of giving up the medical course, a negative association with QOL was observed in all domains, as suggested by another study ${ }^{18}$. Thinking about giving up the course arises at a time of stress concentration, demands and lack of personal fulfillment, affecting all aspects of quality of life, which has an impact not only on academic performance, but also on family and social life, in addition to the negative repercussions on the future professional activity. In this sense, it is important to encourage students to have coping strategies to deal with adverse situations, aiming to prevent the accumulation of psychological stress and thoughts about giving up the course ${ }^{18}$.

This study had some limitations, such as a sample restricted to a single educational institution, in addition to the fact that it is a crosssectional study, that is, the associations found are only of an exploratory nature, without meaning that the associated variables are factors that cause low quality of life. Another limitation was the use of a questionnaire with closed questions, as it did not allow students to express their impressions on quality of life, their association with health and their academic training.

\section{CONCLUSIONS}

The present study found a set of factors capable of interfering with the quality of life of medical students, suggesting the need for interventions aimed at pedagogical and psychological support, in order to guide students about their difficulties and insecurities. It is necessary to create actions aimed at the well-being of these students, as well as strategies aimed to prevent stress in this group. Improving the school environment, providing psychosocial care and encouraging family life is essential in this context.

Among the strategies evidenced as improving the quality of life is the formation of groups to practice physical activity, to talk about healthy diets and a study group. Moreover, the availability of professionals such as psychologists, social workers, among others, is of crucial importance ${ }^{25}$.

Studies like this aim to promote one's reflection about the quality of life of future doctors, because the earlier these professionals reflect on their own life and its quality, the better they will be prepared to assist in the quality of life of their patients, thus developing a more humanized and empathetic medical practice.

The results found herein may contribute to the development of further research on the topic, and it is suggested that future longitudinal studies be carried out to better explore the factors causing low quality of life among medical students, their prevention and proper management.

\section{SOURCES OF FUNDING}

This study was carried out with financial support from Bolsa Pesquisador (Call Out: 02/2018) and Programa Institucional de Bolsas de Iniciação Científica (PIBIC) (Notice n. 2018-2019), by Universidade de Rio Verde (UniRV).

\section{REFERENCES}

1. World Health Organization. Development of the World Health Organization WHOQOL-bref quality of life assessment. Psychol. med. 1998;28(3):551-8.

2. Moreira SNT, Vasconcellos RLSS, Heath N. Estresse na formação médica: como lidar com essa realidade. Rev. bras. educ. med. 2015;39(4):558-64.

3. Pagnin D, Queiroz V. Influence of burnout and sleep difficulties on the quality of life among medical students. Springerplus. 2015;676(4):2-7.

4. Fleck MPA, Louzada S, Xavier M, Chachamovic E, Vieira G, Santos $\mathrm{V}$, et al. Aplicação da versão em português do instrumento abreviado de avaliação da qualidade de vida "WHOQOL-Bref". Rev. saúde pública. 2000;34(2):178-83.

5. Medeiros MRB, Camargo JF, Barbosa LAR, Caldeira AP. Saúde mental de ingressantes no curso médico: uma abordagem segundo o sexo. Rev. bras. educ. med. 2018;43(3):214-221.

6. Langame AP, Chehuen Neto JA, Melo LNB, Castelano ML, Cunha M, Ferreira RE. Qualidade de vida do estudante universitário e o rendimento acadêmico. Rev. bras. promoç. saúde. 2016;29(3):313-25.

7. Cunha DHF, Moraes MA, Benjamin MR, Santos AMN. Percepção da qualidade de vida e fatores associados aos escores de qualidade de vida de alunos de uma escola de medicina. J. bras. psiquiatr. 2017;66(4):189-96.

8. Serinolli MI, Olivia MPM, El-Mafarjeh E. Antecedente de ansiedade, síndrome do pânico ou depressão e análise do impacto na qualidade de vida em estudantes de medicina. Rev. gest. sist. saúde. 2015;4(2):627-33.

9. Aguiar RLB, Aguiar MCM, Merces MC. Síndrome de burnout em estudantes de medicina de universidade da Bahia. Rev Psi Divers Saúde. 2018;7(2):267-6.

10. Chazan ACS, Campos MR, Portugal FB. Qualidade de vida de estudantes de medicina da UERJ por meio do Whoqol-bref: uma abordagem multivariada. Ciênc. Saúde Colet. 2015;20(2):547-56.

11. Ferreira CMG, Kluthcovsky ACGC, Dornelles CF, Stumpf MAM, Cordeiro TMG. Qualidade do sono em estudantes de medicina de uma universidade do Sul do Brasil. Conexão Ci. 2017;12(1):78-85.

12. Irribarra T, Mery I, Lira S, Jesús M, Campos D, González L, et al. Cómo es la calidad de vida reportada por los estudiantes de Medicina? Rev. méd. Chile. 2018;146(11)1294-303.

13. Paro HBMS, Perotta B, Enns SC, Gannam S, Giaxa RRB, Costa FMA, et al. Qualidade de vida do estudante de medicina: o ambiente educacional importa? Rev. med. (São Paulo). 2019; 98(2):140-7.

14. Santos LS, Ribeiro IJS, Boery EN, Boery RNSO. Qualidade de vida e transtornos mentais comuns em estudantes de medicina. Cogitare enferm. 2017;(22)4.

15. Sbroggio Junior AL, Sanchez HM, Arantes Filho WM, Sanchez EG de M, Arantes BM, Guarienti WD, et al. Engagement e qualidade do sono e mais conexões do burnout acadêmico. Rev. Educ. Saúde. 2018;6(2):89-97.

16. Tassini CC, Val GR, Candido SSC, Bachur CKB. Avaliação do estilo de vida em discentes universitários da área da saúde através do Questionário Fantástico. Int. j. cardiovasc. sci. 2017;30(2):117-22.

17. Bührer BE, Tomiyoshi AC, Furtado MD, Nishida FS. Análise da

REVISTA BRASILEIRA DE EDUCAÇC̃̃ MÉDICA

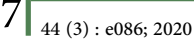


qualidade e estilo de vida entre acadêmicos de Medicina de uma instituição do norte do Paraná. Rev. bras. educ. med. 2019;42(1):39-46.

18. Pereira FEL, Ribeiro CR, Oliveira LMS, Araujo Filho JL, Tabosa MNR, Gouveia Filho PS, et al. Correlatos da qualidade de vida com características de saúde e demográficas de estudantes de medicina. Rev. bras. qual. vida. 2017;9(3):247-60.

19. Serra RD, Mattos SL, Caseiro DMM. Prevalência de sintomas depressivos e ansiosos em alunos de medicina na cidade de Santos. J. bras. psiquiatr. 2015;64(3):213-20.

20. Vasconcelos TC, Dias BRT, Andrade LR, Melo GF, Barbosa L, Souza E. Prevalência de sintomas de ansiedade e depressão em estudantes de Medicina. Rev. bras. educ. med. 2015;39(1):135-42.

21. Conceição LS, Batista CB, Dâmaso JGB, Pereira BS, Carniele RC, Pereira GS. Saúde mental dos estudantes de medicina brasileiros: uma revisão sistemática da literatura. Avaliação. 2019;24(3):785-802.

22. Oliveira ABD. Estresse, síndrome de burnout e qualidade de vida em estudantes de medicina que utilizam metodologia ativa de ensinoaprendizagem: um estudo transversal [dissertação]. Sergipe: Centro de Ciências Biológicas e da Saúde; 2018.

23. Amorim BB, Moraes L, Sá ICG, Silva BBG, Camara Filho JWS. Saúde mental do estudante de medicina: psicopatologia, estresse, sono e qualidade de vida. Rev Psi Divers Saúde. 2018;7(2):245-54.

24. Morgan HL, Petry AF, Licks PAK, Bellester AO, Teixeira KN, Dumith
SC. Consumo de estimulantes cerebrais por estudantes de Medicina de uma universidade do Extremo Sul do Brasil: prevalência, motivação e efeitos percebidos. Rev. bras. educ. med. 2017;41(1):102-9.

25. Moura IH, Nobre RS, Cortez RMA, Campelo V, Macedo SF, Silva ARV. Qualidade de vida de estudantes de graduação em enfermagem. Rev. gaúch. enferm. 2016;37(2):1-7.

\section{AUTHORS' CONTRIBUTION}

Helen Hana Fernandes Tavares, Isabela Maria Melo Miranda, Heloísa Rodrigues Soares da Silva, Monise Santana Braga e Raquel de Oliveira Santos participated in the research design, data collection, data analysis and manuscript writing. Heloísa Silva Guerra participated in the research design, data collection, data analysis, manuscript writing and revision of the final version.

\section{CONFLICTS OF INTEREST}

The authors declare no conflicts of interest

\section{ADDRESS FOR CORRESPONDENCE}

Heloísa Silva Guerra. Alameda Pedro de Sá, s/n, CHC, lt 21E, Jardim dos Buritis, Aparecida de Goiânia, GO, Brasil. CEP: 74923-250.

E-mail: heloisasguerra@gmail.com 